\title{
O pensamento de Martim Lutero sobre razão e revelação na Igreja, na política e na economia
}

\author{
The thought of Martin Luther about reason and revelation in the Church, in \\ politics and in the economy
}

Wilhelm Wachholz*

\begin{abstract}
Resumo
Razão e revelação ocupam lugar destacado na teologia de Martim Lutero, reformador da Igreja no século XVI. A correta relação entre razão e revelação não somente tem implicações teológicas, mas também práticas em relação à Igreja, política e economia. $\mathrm{O}$ objetivo deste artigo é analisar a relação de razão e revelação na teologia de Lutero, em diálogo com Paul Tillich, focando a pergunta pelo conhecimento de Deus e as implicações para Igreja, política e economia. Introdutoriamente, o artigo aborda a problemática do conhecimento. A partir disso, analisa a compreensão de Lutero sobre conhecimento a partir da revelação de Deus na cruz como sub contraria specie. Considerando ter o pecado afetado o conhecimento de Deus e, consequentemente, as relações humanas, o artigo analisa como, para Lutero, Igreja, economia e política precisam ser compreendidos e conclui com as implicações ministeriais do ser humano cristão, considerando os dois reinos, nos três estamentos.
\end{abstract}

Palavras-chave: Razão; Revelação; Igreja; Economia; Política

\begin{abstract}
Reason and revelation occupy a special place in the theology of Martin Luther, reformer of the Church in the 16th century. The correct relation between reason and revelation not only has theological implications but also practical implications with regard to the Church, politics and economy. The goal of this article is to analyze the relation of reason and revelation in Luther's theology in dialog with Paul Tillich, focusing on questioning about the knowledge of God and the implications for the Church, politics and economy. Introductorily, the article deals with the problematic of knowledge. Based on this it analyzes Luther's comprehension of knowledge based on the revelation of God on the cross as sub contraria specie. Considering that sin affected the knowledge of God, and consequently, human relations, the article analyzes how, for Luther, Church, economy and politics need to be understood and concludes with the ministerial implications for the Christian human being, considering the two kingdoms, in the three estates.
\end{abstract}

Keywords: Reason; Revelation; Church; Economy; Politics

Artigo submetido em 06 de junho de 2016 e aprovado em 07 de dezembro de 2016.

* Doutor em Teologia, área de História e Teologia. Professor de Pós-Graduação em Teologia e História na Faculdades EST, São Leopoldo/RS, Brasil, com pesquisa e ensino em História do Cristianismo, História Medieval e Moderna, História e Historiografia. País de origem: Brasil._E-mail: wwachholz@est.edu.br

Horizonte, Belo Horizonte, v. 14, n. 44, p. 1193-1209, out./dez. 2016 - ISSN 2175-5841 


\section{Introdução: revelação e razão e o problema do conhecimento}

Paul Tillich (2014, p. 85), ao analisar o tema da razão e revelação, afirma que a epistemologia e ontologia precisam ser relacionadas de tal forma que a primeira seja parte da segunda. Concretamente isso significa que toda busca de conhecimento precisa interpretar (em movimento circular!) o conhecimento do conhecer (epistemologia) e conhecimento do ser (ontologia). Portanto, conhecimento não se limita à interpretação do acontecimento/evento/objeto, como tendia o Positivismo, mas exige a levada do ser interpretante para dentro da interpretação. Para Tillich, então, não se deveria começar a pergunta pela existência com o problema do conhecimento, mas com a pergunta pelo ser. O ser antecede o pensar. Ainda assim a relação entre ambos é de circularidade, pois o ser é sempre ser pensado (MUELLER, 2005, p. 56).

A teologia, segundo Tillich (2014, p. 85-86), precisa explicitar sempre suas vias ao conhecimento. Constitui-se em erro teológico a afirmação de que a epistemologia seja capaz de fundamentar a teologia. Por isso, caberá à teologia, quando iniciar seu labor com a epistemologia, explicitar bem as antecipações, em particular, seus pressupostos sobre razão e revelação.

Tillich distingue entre razão em perspectiva técnica e em perspectiva ontológica. Em perspectiva técnica, geralmente a razão é reduzida à atividade de "raciocinar", ou seja, indica "[...] atos cognitivos que se ocupam em descobrir os meios mais adequados para alcançar certos fins” (TILLICH, 2014, p. 86-87). Em perspectiva ontológica, tem sentido de logos, de forma a determinar, primeiro, os fins e, somente então, os meios. Já a “[...] razão em sentido técnico determina os meios e se limita em aceitar os fins que lhes são dados desde "fora dela mesma" (TILLICH, 2014, p. 87).

No Iluminismo e Positivismo, segundo Tillich (2014, p. 87), os elementos não-cognitivos da razão foram relegados ao âmbito da subjetividade pura, pois negava-se qualquer possibilidade de “compreender" o que ultrapassasse a razão 
técnica. O resultado desta redução do compreender à razão técnica, contudo, implica o risco da desumanização do ser humano. Mais do que isso, o resultado é também o empobrecimento e a corrupção da própria razão técnica pelo fato de ignorar a razão ontológica. ${ }^{1}$ Ainda assim, segundo Tillich (2014, p. 87-88), a teologia não opta pela razão ontológica em detrimento da técnica. A razão técnica integra a razão ontológica e lhe é companheira, em perspectiva circular. O que a teologia rejeita é confusão entre a razão técnica e ontológica. Um exemplo disso para a teologia é a pergunta pela existência de Deus. Neste caso, a teologia não pode aceitar a ajuda da razão técnica, pois Deus acabaria sendo menos que Ele próprio. ${ }^{2}$ À teologia, portanto, caberá afirmar que a relação da razão com a revelação não pode ser tratada coerentemente no nível da razão técnica. A razão técnica é instrumento e, como tal, mais ou menos perfeita e limitada. Ela se "efetiva no eu e no mundo, é dependente das estruturas destrutivas da existência e das estruturas salvíficas da vida; está sujeita à finitude.” (TILLICH, 2014, p. 88).

A linguagem de Tillich é substantivamente distinta da de Lutero; enquanto Tillich tem no Racionalismo e Positivismo um de seus focos de combate, Lutero o tem, principalmente, com a filosofia aristotélica. Embora com linguagens diferentes, ambos evidenciam aproximações significativas no que diz respeito ao conhecimento. Westhelle contata que, em seus escritos sobre a Disputatio de Homine e nas Preleções sobre Gênesis, Lutero “[...] simplesmente nega a capacidade da filosofia de definir as causas eficiente e final para a existência humana." (WESTHELLE, 2013, p. 324).

No Debate de Heidelberg, Lutero afirma que a cognição natural de Deus é paganismo. O conhecimento de Deus (cognitio Dei) pelo ser humano exige autoconhecimento da condição de finitude de si mesmo; a negligência do autoconhecimento se constitui na raiz de toda idolatria. (LUTERO, 2014, p. 172173, 352-354). Lutero denuncia, então, a tentativa de uma cognição natural plena 
de Deus como "cognição de Deus a partir das obras". (LOEWENICH, 1988, p. 22; ALTHAUS, 2008, p. 85). A tentativa do conhecimento de Deus pela razão natural implicaria em diminuir Deus de si mesmo, ou seja, privá-lo de sua liberdade. O ser humano, por sua vez, ocuparia o lugar Deus, o que, contudo, contradiria a própria natureza finita humana, evidenciando-se, fundamentalmente, como impossibilidade.

\section{Conhecimento de Deus sub contraria specie}

Enquanto Tillich distingue entre razão ontológica e razão técnica quando aborda o tema do conhecimento, Lutero distingue entre duas espécies de conhecimento de Deus (duplex est cognitio Dei), que exigem correta definição da relação entre razão e revelação. O primeiro conhecimento de Deus, acessível a todo ser humano, é o conhecimento "geral" ou "natural". O segundo, dado somente através da fé em Cristo, é o conhecimento "particular” ou “próprio" (proprius). Lutero consente a possibilidade de um conhecimento geral de Deus, mas este é um conhecimento somente à “distância”, que não permite ir ao "miolo”, pois, sem fé, pretende conhecer Deus, dissecando-o como objeto de análise. O conhecimento proprium de Deus é conhecimento através do qual Deus se dá a conhecer (revelação). "Cristo é o único meio e, como se poderia dizer, o espelho através do qual vemos a Deus, isto quer dizer, através do qual conhecemos a sua vontade”. (ALTHAUS, 2008, p. 83). Por isso, buscar por Deus em outro lugar que não Cristo e encontrar o diabo (LUTERO, 1993, p. 207; LUTERO, 1993, p. 369). Por esta razão, o conhecimento "real” de Deus exige fé de forma que Deus e fé são inseparáveis. Somente a conjugação entre ambos permite a compreensão do que significa Deus. A este respeito, o reformador afirma no Catecismo Maior:

"Não terás outros deuses." Isto é: considerarás somente a mim como teu Deus. Que significa isso e como se deve entendê-lo? Que significa ter um Deus, ou, que é Deus? Resposta: Deus designa aquilo de que se deve esperar todo o bem e em que devemos refugiar-nos em toda apertura. 
Portanto, ter um Deus outra coisa não é senão confiar e crer nele de coração. Repetidas vezes já disse que apenas o confiar e crer de coração faz tanto Deus como ídolo. Se é verdadeira a fé e a confiança, verdadeiro é o teu Deus. Inversamente, onde a confiança é falsa e errônea, aí também não está o Deus verdadeiro. Fé e Deus não se podem divorciar. Aquilo, pois, a que prendes o coração e te confias, isso, digo, é propriamente o teu Deus. (LUTERO, 2000, p. 333-334).

O Deus verdadeiro somente pode ser conhecido a partir do Cristo crucificado. Por ser conhecimento a partir da cruz, a cognição de Deus é cognição sub contraria specie, isto é, paradoxal de sua revelação e ocultação. Ao ocultar-se na cruz, Deus paradoxalmente se revela, ou seja, revela "humanidade, debilidade, tolice" (LUTERO, 1987, p. 49), ocultando sua divindade, glória, majestade. Assim, Deus se visibiliza ao se ocultar e somente ao se ocultar, se visibiliza. A cruz - e isso vale também para o agir de Deus através de Igreja, economia e política - é, então, "máscara" ou "véu" utilizada para sua auto-revelação.

Assim, não basta nem adianta a ninguém conhecer a Deus em glória e majestade se não o conhece também na humildade e na ignomínia da cruz. Desta maneira, ele destrói a sabedoria dos sábios, etc., conforme diz Isaías: "Verdadeiramente tu és Deus abscôndito." (LUTERO, 1987, p. 50).

A partir da teologia da cruz, Lutero caracteriza a revelação de Deus como sendo, então, sub contraria specie. Desta forma, Lutero, que neste ponto é seguido por Tillich (MUELLER, 2005, p. 62), concebe conhecimento de Deus a partir da perspectiva cristológica, segundo a qual Deus não exclui o que lhe é contrário, por exemplo, a matéria ou forma humana, mas o assume, de tal forma que estabelece permuta de qualidades de natureza e destino. Assim, história e sentido são indissociáveis em Deus. Por isso, a cruz (história) aponta para o seu contrário, ou seja, a vida (sentido). A encarnação é, então, para Lutero, "permuta alegre" (fröhlicher Wechsel); ao sujeitar-se à cruz, os humilhados são exaltados, ao ser injustiçado, os injustiçados recebem a justiça, ao morrer, os mortos têm a vida. (LUTERO, 2012, p. 19). 
O ser de Deus na cruz, que é paradoxalmente também o seu não ser, não permite um conhecimento de Deus pela via da metafísica. A exclusão da metafísica por Lutero se dá pelo fato de que esta representa a tentativa de um caminho de conhecimento direto de Deus. Na cruz, se evidencia que Deus se oculta ao se instrumentalizar do finito. Ao mesmo tempo em que se instrumentaliza, se oculta nos próprios instrumentos de mediação. Por isso, o conhecimento de Deus pelo caminho da metafísica é especulação sobre Deus. (LOEWENICH, 1988, p. 21.). Inversamente, Deus também permanece oculto nos acontecimentos históricos. Tentar "ler" a vontade de Deus diretamente a partir da história é pura ilusão e não seria "sabedoria", pois sabedoria é sempre sub contraria specie, isto é, sabedoria na fé. Aliás, se olharmos para a história e para a natureza, teremos somente a face da terrível majestade de Deus. (PINOMAA, 1964. p. 69). Disso se deve concluir preliminarmente, que a história não é juíza de si mesma, como o próprio Lutero percebia, pelo fato de a história ser história de Deus e seu sentido estar em Deus.

A instrumentalização de Deus em Cristo, isto é, a revelação de Deus em Cristo, é a realização de Deus para dentro da realidade humana. Contudo, Deus não se esgota na revelação, ou no nível da realidade humana, razão pela qual é necessário distinguir entre o Deus revelado/Palavra de Deus e Deus em si mesmo. (LOEWENICH, 1988, p. 28). Esta distinção é necessária para que a razão não afirme como verdade somente aquilo que não lhe ultrapasse o domínio. Neste caso, o resultado seria o fundamentalismo religioso, cultural, político, econômico.

A teologia cristocêntrica e ideias ontológicas se fazem perceber no pensamento de Lutero. Para ele, "compreende[-se] as coisas visíveis e posteriores de Deus enxergando-as pelos sofrimentos e pela cruz.” (LUTERO, 1987, p. 49). A cognição “das coisas invisíveis” somente é possível a partir da pessoa de Cristo. Lutero tem ciência de que a filosofia também busca as coisas invisíveis, contudo, para ele, ela o faz especulando, enquanto a teologia o faz contemplando. Segundo Loewenich, 
Se a filosofia, não obstante, chega a abstrações, isto somente lhe é possível através de inferências deduzidas das percepções, portanto, não pela via direta como na antiga filosofia ontológica de Agostinho e Anselmo, através de um "cheirar" ou "tocar". (LOEWENICH, 1988, p. 56).

Lutero afirma a paradoxalidade de revelação e ocultação de Deus em Cristo. Em Cristo, Deus é Deus revelado. Contudo, “[...] na medida em que Deus se oculta e quer ser ignorado por nós, ele absolutamente não nos importa”. (LUTERO, 1993, p. 101). E o que Deus deixa abscôndito assim o deve ser porque não quer se reconhecido por nós. Isso, contudo, não significa que não nos interessa, mas que neste âmbito não há commercium (negócio). Este, então, é o âmbito da fé. (LOEWENICH, 1988, p. 29-30).

A paradoxalidade, contudo, ocorre também no âmbito do próprio revelado, pois ela é, em sua essência, paradoxal: "que Deus se revelou a si mesmo e que Deus é um mistério infinito para as pessoas a quem ele se revelou". (TILLICH, 2014, p.122). A própria razão não fica absolutamente excluída da revelação, segundo Tillich, pois ela encontra na revelação respostas a perguntas últimas que lhe dirige. Mas na revelação, a razão também "é conduzida para além de si mesma, a seu 'fundamento e abismo"'. (TILLICH, 2014, p. 122). A revelação nos evidencia aquilo de último que nos diz respeito, a saber, "o fundamento de nosso ser". (TILLICH, 2014, p. 123). Razão e revelação, então, se encontram. Segundo Mueller, "o fundamento da razão é o fundamento do ser, são o mesmo. Só o processo de alienação os separou." (MUELLER, 2005, p. 63). Em Lutero, isso implica afirmar que conhecimento de Deus e conhecimento de si mesmo se encontram e não devem ser separados. Em Tillich, implica dizer que a razão como um todo, incluindo a razão técnica, que vai além de si mesma, tornando-se auto-transcendente ou extática, precisa estar aberta a seu fundamento e abismo.

A paradoxalidade de revelação e ocultação coloca o ser humano no âmbito da fé. A fé diz respeito ao Deus abscôndito. Sem o Deus abscôndito, Deus deixa de ser Deus, e a fé é "substituída" por uma razão técnica, que reduz Deus a um objeto de cognição direta. Em outras palavras, a fé, que busca Deus, tem seu lugar 
ocupado pela razão técnica que pretende ter Deus. (LOEWENICH, 1988, p. 77). A redução de Deus pela razão técnica a objeto/posse tem reflexos na ética, em particular, no âmbito da política, economia e Igreja.

A tensão entre fé e razão, ou entre razão técnica e ontológica, somente cessará na eternidade. Isso é assim, pois, enquanto a fé conduz a pessoa crente, durante a vida de pecado e morte, pelo caminho da esperança, a razão, se pauta na experiência racional, nas coisas aparentes, enxergando as “coisas como são" (LOEWENICH, 1988, p. 76-77)

\section{Igreja, economia e política e o pecado}

Em suas Preleções sobre Gênesis, Lutero afirma que, em consequência da queda, o ser humano teve sua natureza corrompida de forma múltipla - Tillich, emprega o conceito de alienação (MUELLER, 2005, p. 62). Isso implica também o conhecimento de Deus (LUTERO, 2014, p. 166), de forma que, “[...] na Teologia, a razão nos seres humanos é grande inimiga de Deus". (LUTERO, 2014, p. 167). A partir da queda, o ser humano buscou, pela razão, o conhecimento "autônomo" de Deus. Mas há que se considerar que nenhuma "centelha do conhecimento de Deus" permaneceu íntegra no ser humano. (LUTERO, 2014, p. 320). Como consequência, também as relações ser humano-Deus e as relações éticas ser humano-ser humano ficaram corrompidas pelo pecado.

As implicações éticas das relações Deus-pessoa e pessoa-pessoa precisam considerar os três estamentos (Stände), como máscaras (larvae) através das quais e pelas quais Deus atua. Lutero assume o princípio medieval, segundo a qual a humanidade foi ordenada por Deus em três estamentos, a saber, a Igreja (ecclesia), o lar/domicílio (oeconomia) e o Estado (politia). A instituição e o papel de cada estamento são assim definidos por Lutero: 
Essa é a instituição da Igreja, antes que houvesse organização econômica e política, pois Eva ainda não fora criada. A Igreja é instituída sem muros e sem qualquer pompa, num lugar muito amplo e agradável. Depois da instituição da Igreja, organiza-se também o regime doméstico, quando se dá Eva a Adão como parceira. Dessa maneira, o templo é anterior à casa, o que [aliás,] também é melhor. Tampouco houve organização política antes do pecado, porque não era necessária. Pois a organização política é o remédio necessário para a natureza corrompida. A paixão precisa ser reprimida pelos grilhões da lei e pelos castigos, para que ela não vagueie livremente. Por isso, chama-se corretamente a organização política de reino do pecado, assim como Paulo chama Moisés de ministro da morte e do pecado. Pois é exclusiva e principalmente isto que a organização política faz; conter o pecado, conforme diz Paulo: "A autoridade carrega a espada para a punição dos maus" (Rm 13.4). Portanto, se os seres humanos não tivessem se tornado maus através do pecado, a organização política não teria sido necessária, mas Adão teria vivido com seus descendentes na máxima tranquilidade e teria realizado mais mexendo um só dedo do que podem realizar agora todas as espadas, instrumentos de tortura e machados. Não teria existido assaltante, homicida, ladrão, difamador, mentiroso. Ora, que necessidade teria havido de leis, de organização política, que são como um cautério e um remédio terrível por meio do qual se amputam membros nocivos para salvar as demais? (LUTERO, 2014, p. 134-135). ${ }^{3}$

Somente a Igreja e a economia são, então, ordens da criação, enquanto a política, ainda que ordenada por Deus, o foi após a queda do ser humano. (WESTHELLE, 2013, p. 325-326).

Portanto, depois que se estabeleceu a Igreja, também se confiou a organização econômica a Adão no paraíso. Mas a Igreja foi instituída primeiro, para que Deus mostrasse com esse sinal que o ser humano foi criado com um propósito diferente dos demais seres vivos. Pelo fato [da Igreja] ter sido instituída pela Palavra de Deus, é certo que [o ser humano] foi criado para a imortalidade e para a vida espiritual, para a qual teria sido arrebatado ou transferido, mas sem morte, depois que tivesse vivido por longo tempo e sem moléstia no Éden e no resto da terra. (LUTERO, 2014, p. 135).

Ainda que não devam ser confundidos como ordens da criação, em comum os três estamentos têm o fato de serem "máscaras" para a ação de Deus no mundo. A Igreja é instrumento de Deus para que sua Palavra seja testemunhada à criação, como força que move à resposta humana. A economia (oeconomia = domicílio) diz respeito às relações domiciliares/domésticas, a saber, de produção e reprodução

${ }^{3}$ Veja também WESTHELLE, 2013, p. 329. 
humanas, ou seja, diz respeito à produção e reprodução da sustentação da vida. A política diz respeito à administração dos meios para o sustento, proteção e defesa da vida. (WESTHELLE, 2013, p. 317, 322.).

Segundo Westhelle (2013, p. 326-327) economia e a política precisam ser compreendidas a partir e na relação com a queda no pecado. Para Lutero, no início, havia economia. A ordenação da política decorre da economia afetada pelo pecado. No paraíso, portanto, havia somente economia. No momento em que esta foi distorcida por causa do pecado, a política surge como defesa da integridade econômica. Nesta relação, portanto, o econômico não somente é anterior, mas também tem primazia sobre o político. Valendo-se de Oswald Bayer, Westhelle afirma que "a política é instituída por causa da produção e reprodução da vida, e não o inverso.” (WESTHELLE, 2013, p. 327). Segundo o próprio Lutero,

Deus dá a Adão duas tarefas, ou seja, que trabalhe ou cultive esse jardim e, também, que o proteja e o vigie. Alguns vestígios dessa ordem subsistem nos miseráveis restos que ainda temos. Pois, até hoje, essas coisas devem estar conjugadas: que a terra não apenas seja cultivada, mas também que a [terra] cultivada seja conservada. As duas tarefas foram deturpadas de infinitas maneiras. [...]

Pois assim como o ser humano caiu no espírito, mediante o pecado, ele também atraiu o castigo sobre o seu corpo. Pois o trabalho, que no estado de inocência teria sido diversão e prazer, [agora] é um castigo. (LUTERO, 2014, p. 134).

E acrescenta:

Estou inteiramente convencido de que, no paraíso, teria havido uma eterna primavera, sem qualquer inverno, sem neve nem frio, como existem hoje, depois do pecado. (LUTERO, 2014, p. 168).

\section{Ministérios a serviço da esperança}

A fé é a spes (esperança) que atua no amor contra a res (realidade) do pecado e alienação.4 Para Lutero, “esperança em sentido estrito sempre é um 'esperar o contrário', está sempre contestando a realidade ao nosso redor.”

${ }^{4}$ Sobre a definição de in re e in spes, na perspectiva da teologia e filosofia, veja MUELLER, 2007, p. 88-103. 
(LOEWENICH, 1988, p. 87; ALTHAUS, 2008, p. 72). Isso somente é possível, pois "nossa justiça não está na realidade concreta, mas na esperança." (LOEWENICH, 1988, p. 88). A spes é spes que deriva do conhecimento de Deus na cruz, ao mesmo tempo em que é spes contra a cruz. Neste sentido, a ação ética é originada e alimentada, mediante a fé, a partir da spes contra a res do pecado e da alienação.

A política, então, segundo Westhelle (2013, p. 329-330), em perspectiva de spes, tem como finalidade restabelecer as relações econômicas. Considerando o pecado como alienação e corrupção, cabe à política restabelecer a equidade e justiça econômica da polis. Evidentemente, temos aqui um problema fundamental: os agentes da política são pessoas afetadas pela queda. Lutero tem ciência de que, por causa do pecado, a política, assim como o próprio exercício do amor por qualquer pessoa cristã 5 , está sujeita à imperfeição. Governantes realmente cristãos são desejáveis e o melhor para o povo, pois abdicariam "da ideia de querer governar e proceder com violência [, uma vez que] [...] maldita e condenada é toda vida que se vive e busca em benefício próprio [e] malditas todas as obras não inspiradas pelo amor" (LUTERO, 2016, p. 106). Contudo, "ainda que não sejam cristãos, devem agir correta e benfazejamente, segundo a ordem exterior de Deus; isto é que ele quer deles" (LUTERO, 2016, p. 388)

Juízo e não um suposto caráter cristão confere legitimidade à autoridade secular. Juízo, neste caso, pode ser relacionado com conhecimento "geral" ou "natural”6 (Lutero) de Deus. Um bom governo, então, pressupõe o correto "juízo racional”. E é neste sentido que Lutero interpreta Moisés que somente pode ser tomado como legislador se coincidir "[...] com o Novo Testamento ou com a lei natural." (LUTERO, 2003, p. 186-187). No que se refere ao Novo Testamento, Moisés deve ser considerado na medida em que não aponta para si próprio, mas quando nele “[...] se encontram ali as promessas de Deus que fortalecem e mantém

\footnotetext{
${ }^{5}$ Sobre antropologia cristã em Lutero, veja LUTERO, 1993, p. 11-216.

${ }^{6}$ Lutero, explicitamente, afirma, a partir dos mandamentos proclamados por Moisés, que "[....] é natural glorificar a Deus, não furtar, não cometer adultério, não prestar falso testemunho, não cometer homicídio, não sendo novidade aquilo que Moisés preceitua. Pois aquilo que Deus transmitiu do céu aos judeus por meio de Moisés, ele também o escreveu nos corações de todas as pessoas, tanto dos judeus quanto dos gentios [...]." (LUTERO, 2003, p. 189).
} 
a fé”, ou seja, tudo que se refere a Cristo. (LUTERO, 2003, p. 189-190). No que se refere à lei natural, Moisés pode ser tomado como mestre “[...] por dar belos exemplos de leis para o bom e ordeiro governo do país e do povo em questões exteriores.” (LUTERO, 2003, p. 189.). A partir desta interpretação de Moisés, Lutero distingue entre os dois reinos, a saber,

o secular, que governa com a espada e é visto exteriormente; e o espiritual, que rege apenas com a graça e o perdão dos pecados, sendo que este Reino não pode ser visto com olhos físicos, mas é apreendido apenas com a fé. (LUTERO, 2003, p. 185).

O contexto da interpretação de Moisés por Lutero é o do combate tanto aos romanistas quanto aos reformadores radicais. Os reformadores radicais, em particular Tomás Müntzer e os anabatistas, são combatidos pelo fato de se afirmarem como os verdadeiros cristãos e tentarem uma espécie de “personalização” do Reino de Deus neles e suas consequentes propostas de governo na terra. Diferente de outros movimentos radicais, que tendiam a isolar-se da sociedade circundante, vivendo o "próprio reino”, Müntzer e seu movimento, tendiam, pela violência, se necessário, implantar o reino milenar de Cristo na terra, constituído de somente pessoas santas. (GASSMANN; HENDRIX, 2002, p. 137). Lutero, rejeitando pretensões teocráticas, "propôs que a jurisdição eclesiástica deveria estar desprovida de competência em questões temporais.” (LIENHARD, 1998, p. 81). Ele entende que nem o caminho dos reformadores radicais nem dos romanistas condiz com os princípios cristãos, pelo fato de confundirem ou separarem os dois reinos. Em ambos os casos, a recorrência a Moisés como legislador, por confundir Lei e Evangelho e, em instância última, reduzir conhecimento de Deus pela razão, resulta na redução do reino espiritual ao reino temporal em caráter legalista e fundamentalista.

Lutero, segundo Altmann (1994, p. 161), entende que reino espiritual e reino secular, assim como Estado e Igreja não devem ser reduzidos um ao outro nem tornadas entidades autônomas. Reduzidos um ao outro, o reino espiritual poderia ficar alienado por projetos utópicos de concreção do Reino de Deus na terra. 
(GASSMANN; HENDRIX, 2002, p. 138). Separados, o resultado seria o de uma Igreja a-política, descomprometida com seu testemunho no mundo. A relação entre ambos deveria ser de cooperação:

Cabia à autoridade política efetuar reformas políticas, econômicas e sociais que afetassem também a Igreja; e competia a esta confrontar as autoridades políticas com a vontade de Deus. Pois os assim chamados "dois reinos" se distinguem em atribuição e meios, mas se cobrem em espaços. Pois estão vinculados em sua base e em sua finalidade: Deus é o Senhor de ambos, o ser humano a finalidade de ambos. Estado e Igreja ficam assim instrumentalizados, limitando-se e vinculando-se reciprocamente. O Estado limita e regulamenta a Igreja enquanto instituição social [...]. A Igreja proclama a vontade de Deus ao Estado. (ALTMANN, 1994, p. 161).

Os dois reinos são de Deus, ou seja, são regimes ou formas de governos de Deus no mundo, para realização de Sua obra. Para o exercício do governo secular ou temporal, Deus realiza sua obra no "primeiro uso da lei”, a saber, o "uso civil da lei” (EBELING, 1988, p. 148), ou usus civilis ou politicus, conforme caracterização de Lutero. Neste caso,

ela tem sua necessidade positiva, construtiva, ordenadora e preservadora de vida, possibilitadora de justiça [...] [e] [...] nada mais pretende do que a justiça terrena e civil, isto é, limitar as consequências do pecado e refrear o ser humano. (EBELING, 1988, p. 108-109).

Neste caso, a razão, o juízo são condições fundamentais para um bom governo secular, de forma que um bom governo pode ocorrer por pessoa pagã (embora, como afirmado assim, desejável é pessoa cristã, pelas razões expostas):

De fato, Deus subordinou e sujeitou o regime secular à razão, porque não deve governar a salvação das almas, nem bens eternos, mas tão-somente bens físicos e temporais que Deus sujeita ao ser humano [...]. Por essa razão, não se ensina no Evangelho a respeito de como deve ser administrado e governado, exceto que ordena que se deve honrá-lo e não lhe resistir. Por isso os gentios podem falar e ensinar muito bem a respeito desse assunto (como, na verdade, fizeram). E para dizer a verdade, eles são bem mais hábeis nesses negócios do que os cristãos [...]. Pois Deus é um senhor generoso e rico, que lança ouro, prata, riquezas, domínios e reinos em grande quantidade nas mãos dos gentios, como se fosse palha e areia. Da mesma forma distribui entre eles grande inteligência, sabedoria, 
conhecimentos linguísticos e eloquência, de sorte que seus amados cristãos parecem meras crianças, tolos e mendigos em comparação com eles. (LUTERO, 2016, p. 187-188).

A distinção - não a confusão nem a separação - dos dois reinos é necessária pela própria relação do ser humano cristão com o mundo. A pessoa cristã está no mundo, mas não é do mundo. O conceito mundo, portanto, é ambivalente. De um lado, "mundo" indica a parte da criação de Deus que não reconhece nem confessa Deus como criador. Trata-se do "mundo" sob o poder do diabo.7 De outro lado, expressa a boa criação de Deus, instituída e regida por Deus através de leis e autoridades. Trata-se do mundo político ou secular. Neste âmbito, caberá ao ser humano cristão a cooperação com Deus no sentido de testemunhar sua fé em spes através do amor ministerial.

À Igreja, comunhão de pessoas simul iustus et peccator, cabe o testemunho da spes para dentro da e contra a res através dos ministérios nos três estamentos. Deus incumbe pessoas, “[...] seja na administração da casa ou no governo e na Igreja [...]"; por isso, "não abandonemos, por este motivo [a impaciência], o governo, a economia [do lar] ou a nossa preocupação com a Igreja.” (LUTERO, 2014, p. 231).

Pois onde existe um ministério, não devemos esperar uma revelação, seja interna ou externa. Caso contrário, todos os estamentos da vida seriam confundidos. O ministro deve ensinar na Igreja, o magistrado deve governar o Estado, os pais devem governar a casa ou o domicílio. Esses ministérios foram instituídos por Deus para [benefício d]os seres

\footnotetext{
${ }^{7}$ Neste sentido, cabem algumas referências de Lutero no Catecismo Maior. Referente ao primeiro artigo de Credo Apostólico, afirma Lutero: “Porque, se o crêssemos de coração, também agiríamos de acordo, e não andaríamos por aí tão orgulhosos, não nos mostraríamos desafiantes e não nos ufanaríamos, como se tivéssemos de nós mesmos a vida, a riqueza, o poder, a honra, etc., de sorte que se tivesse de temer e servir a nós. É assim que procede o infeliz e pervertido mundo, que está afogado em sua cegueira e mal-usa todos os bens e dons de Deus unicamente para a sua soberba, avareza, prazer e diversão, sem atentar uma vez sequer em Deus, para agradecer-Ihe e reconhece-lo com Senhor e Criador. Razão por que este artigo a todos nos humilharia e assombraria, se o crêssemos. Porque diariamente pecamos com os olhos, ouvidos, mãos, corpo e alma, dinheiro e bens, e com tudo o que temos." (LUTERO, 1997, p. 449). (grifo nosso). Sobre a sexta petição do Pai-Nosso, Lutero afirma: "Além disso, é o mundo que nos ofende com palavras e obras e nos impele a cólera e impaciência. Em resumo, aí nada há senão ódio e inveja, inimizade, violência e injustiça, infidelidade, vingança, imprecação, ralho, maledicência, orgulho e soberba, juntamente com excesso de adorno, honra, fama e poder, onde ninguém quer ser o menor, mas cada qual quer sentar-se à cabeceira e ser visto antes de qualquer outro." Sobre a última petição do Pai-Nosso, Lutero afirma que oramos para que Deus nos livre de toda desgraça no mundo, o que inclui o mal que "[...] pode nos suceder sob o reino do diabo: pobreza, vergonha, morte, e, em resumo, toda a desventurada miséria e dor, que existe em profusão inumerável na terra." (LUTERO, 1997, p. 471, 473). (grifo nosso).
} 
humanos; por isso deve-se fazer uso deles e não esperar por outras revelações. (LUTERO, 2014, p. 303).

Por esta razão, a fé se caracteriza como spes contra a res do pecado e da alienação: "Seremos capazes de fazer isso se opusermos a essas dificuldades temporárias a esperança da ressurreição e da vida eterna.” (LUTERO, 2014, p. 231). O exercício do ministério é ordem divina. Para isso, Lutero evoca a ordem dada a Abraão:

essas palavras - "Assim lhe ordenou o Senhor" - deveriam ser escritas com letras douradas, não só em paredes, mas em todos os nossos ditos e atos. Pois elas ensinam que a verdadeira obediência consiste em ouvir e seguir a Palavra de Deus que é dita para ti. Onde não existe a Palavra, ali ou não existe obediência ou existe obediência satânica. Por esse motivo, é necessário considerar a Palavra em toda a vida em todas as atividades, não só na Igreja, mas também na economia e na política. (LUTERO, 2014, p. 374).

\section{Conclusão}

Lutero e Tillich situam-se em "dois mundos" distintos, com linguagens distintas. Buscamos uma aproximação entre ambos a partir do problema do conhecimento. Ambos entendem que pecado e alienação humana afastaram o ser humano de si mesmo e de Deus. Alienação e pecado se expressam como força diabólica (dia-bolein), de separação, fragmentação das relações, de ameaça à vida. A spes cristã é, então, força contra a res dia-bolein. Em Lutero, a spes tem sua expressão através dos ministérios aos quais Deus incumbe às pessoas na Igreja, na política e na economia.

A incumbência ministerial por Deus exige correta compreensão da relação de razão e revelação. O conhecimento de Deus pela cruz exige distinção entre Deus revelado e abscôndito. Deus não pode ser, então, "desmascarado" ou "lido" absolutamente na história por uma razão técnica, como denunciou Tillich em relação ao pensamento do século XIX. A tentativa de desmascarar Deus pela razão implicaria em não deixar Deus ser Deus; o ser humano, então, ocuparia este espaço. Por isso, citando Tillich, pode-se afirmar que a teologia não pode se 
submeter à razão técnica, pois Deus seria subtraído de si, e tornado menos que Ele próprio. A consequência disso seria, ao ignorar sua natureza finita e pecadora, que o ser humano acabaria por idolatrar a si próprio. E ao fazê-lo, se apropriaria dos estamentos de Deus, isto é, Igreja, economia e política, patrocinando uma res fundamentalista e diabólica, 8 ao invés de agir ético em spes contra a res do pecado, em favor da produção e reprodução da vida.

\section{REFERÊNCIAS}

ALTHAUS, Paul. A teologia de Martinho Lutero. Canoas: Ulbra; Porto Alegre: Concórdia, 2008.

ALTMANN, Walter. Lutero e Libertação. São Leopoldo: Sinodal; São Paulo: Ática, 1994 .

BAYER, Oswald. A teologia de Martim Lutero; uma atualização. São Leopoldo: Sinodal, 2007.

EBELING, Gerhard. O Pensamento de Lutero. São Leopoldo: Sinodal, 1988.

GASSMANN, Günther; HENDRIX, Scott. As Confissões Luteranas: introdução. São Leopoldo: Sinodal, 2002.

LIENHARD, Marc. Martim Lutero; tempo, vida e mensagem. São Leopoldo: Sinodal/IEPG, 1998.

LOEWENICH, Walther von. A teologia da cruz de Lutero. São Leopoldo: Sinodal, 1988.

LUTERO, Martinho. Acerca da questão, se também militares ocupam função bemaventurada. In: LUTERO. Martinho. Obras Selecionadas - v. 6. 2. ed. São Leopoldo: Sinodal; Porto Alegre: Concórdia; Canoas: Ulbra, 2016. p. 360-401.

LUTERO, Martinho. Catecismo Maior. In: LUTERO. Martinho. Livro de Concórdia; as confissões da Igreja Evangélica Luterana. São Leopoldo: Sinodal; Porto Alegre: Concórdia, 1997. p. 385-496.

LUTERO, Martinho. Como lidar com Moisés. In: LUTERO. Martinho. Obras

Selecionadas - v. 8. São Leopoldo: Sinodal; Porto Alegre: Concórdia, 2003. p. 183-195.

${ }^{8}$ Diabólico se origina do grego dia-bolein e significa "dividir". Logo, diabólico é aquilo que divide, separa, aliena, corrompe. 
LUTERO, Martinho. Da Autoridade Secular, até que ponto se lhe deve obediência. In: LUTERO. Martinho. Obras Selecionadas - v. 6. 2. ed. São Leopoldo: Sinodal; Porto Alegre: Concórdia; Canoas: Ulbra, 2016. p. 79-114.

LUTERO, Martinho. Da Ceia de Cristo - Confissão. In: LUTERO. Martinho. Obras Selecionadas - v.4. São Leopoldo: Sinodal; Porto Alegre: Concórdia, 1993· p. 217-375.

LUTERO, Martinho. Da Liberdade Cristã. 8. ed. São Leopoldo: Sinodal, 2012.

LUTERO, Martinho. Da Vontade Cativa. In: LUTERO, Martinho. Obras Selecionadas v.4. São Leopoldo: Sinodal, Porto Alegre: Concórdia, 1993. p. 11-216.

LUTERO, Martinho. Gênesis. In: LUTERO. Martinho. Obras Selecionadas - v. 12. São Leopoldo: Sinodal; Porto Alegre: Concórdia, Canoas: Ulbra, 2014. p. 53-530.

LUTERO, Martinho. O Debate de Heidelberg. In: LUTERO. Martinho. Obras Selecionadas - v. 1. São Leopoldo: Sinodal; Porto Alegre: Concórdia, 1987. p. 37-54.

LUTERO. Martinho. Salmo 101. In: LUTERO. Martinho. Obras Selecionadas - v. 6. 2. ed. São Leopoldo: Sinodal; Porto Alegre: Concórdia; Canoas: Ulbra, 2016. p. 138-213.

MUELLER, Enio R. A teologia e seu estatuto teórico: contribuições para uma discussão atual na universidade brasileira. Estudos Teológicos, Sa $\square$ o Leopoldo, v. 47, n. 2, p. 88$103,2007$.

MUELLER, Enio Ronald. Caminhos do Pensar. In: MUELLER, Enio R.; BEIMS, Robert W. Fronteiras e Interfaces; o pensamento de Paul Tillich em perspectiva interdisciplinar. São Leopoldo: Sinodal, 2005, p. 42-65.

PINOMAA, Lennart. Sieg des Glaubens; Grundlinien der Theologie Luthers. Göttingen: Vandernhoeck \& Ruprecht, 1964.

TILLICH, Paul. Teologia Sistemática. 7. ed. São Leopoldo: Sinodal/EST, 2014.

WESTHELLE, Vítor. Poder e Política - incursões na teologia de Lutero. In: HELMER, Christine. Lutero: um teólogo para tempos modernos. São Leopoldo: Sinodal, 2013, p. 315-331. 